\title{
The Effect of Green Human Resource Management on Organization Citizenship Behaviour for Environment (OCBE) and Its Implications on Employee Performance at PT Andalan Bakti Niaga
}

\author{
Ari Saputro and Lenny Christina Nawangsari
}

\section{ABSTRACT}

This study aims to analyze the effect of Green Human Resource Management on Employee Performance through Organization Citizenship Behavior for Environment (OCBE). This type of research uses a survey method with a quantitative approach. This research was conducted at PT Andalan Bakti Niaga. Sampling using nonprobability techniques with a sample size of 80 people. Data analysis in this study used Structural Equation Modeling (SEM) with Partial Least Square (PLS) software version 3.2.7. The results obtained in this study: 1) Green Recruitment, Green Training, Green Compensation and Rewards have a positive and significant effect on OCBE; 2) Green Performance Appraisal has no significant effect on OCBE; 3) Green Training and Green Performance Appraisal have a positive and significant effect on Employee Performance; 4) Green Recruitment and Green Compensation and Rewards have a negative and significant effect on Employee Performance; 5) OCBE has a positive and significant effect on Employee Performance; 6) Green Recruitment, Green Training, Green Compensation and Rewards have a significant effect on Employee Performance through OCBE; 7) Green Performance Appraisal has no significant effect on Employee Performance through OCBE; 8) Green Human Resource Management has a significant effect on OCBE; 9) Green Human Resource Management has a significant effect on Employee Performance.

Submitted : January 29, 2021

Published : February 19, 2021

ISSN: 2507-1076

DOI: $10.24018 / \mathrm{ejbmr} .2021 .6 .1 .716$

\section{Ari Saputro*}

Mercu Buana University, Jakarta, Indonesia.

(e-mail: saputro.arri@gmail.com)

Lenny Christina Nawangsari

Mercu Buana University, Jakarta,

Indonesia.

(e-mail: lenny.christina ${ }^{\circledR}$ mercubuana.ac.id)

*Corresponding Author

Keywords: Green Human Resource Management, Green Recruitment, Green Training, Green Compensation and Rewards, Green Performance Appraisal, Organization Citizenship Behavior for Environment (OCBE), Employee Performance.

\section{INTRODUCTION}

In facing competition in the era of globalization, every company is required to work more effectively and efficiently. Every company will always strive to improve employee performance, with the hope that what the company's goals can be achieved. The performance of these employees is one of the assets for the company to achieve its goals. Increasing employee performance will also have an impact on improving company performance. Therefore, employee performance is something that must be considered by company leaders.

As one of the companies formed based on the needs of the industrial world, PT Andalan Bakti Niaga tries to play an active role in the automotive world by becoming a distributor of lubricating oil. Regarding employee appraisals, PT Andalan Bakti Niaga conducts employee appraisals which include performance, work attitudes, and competencies.

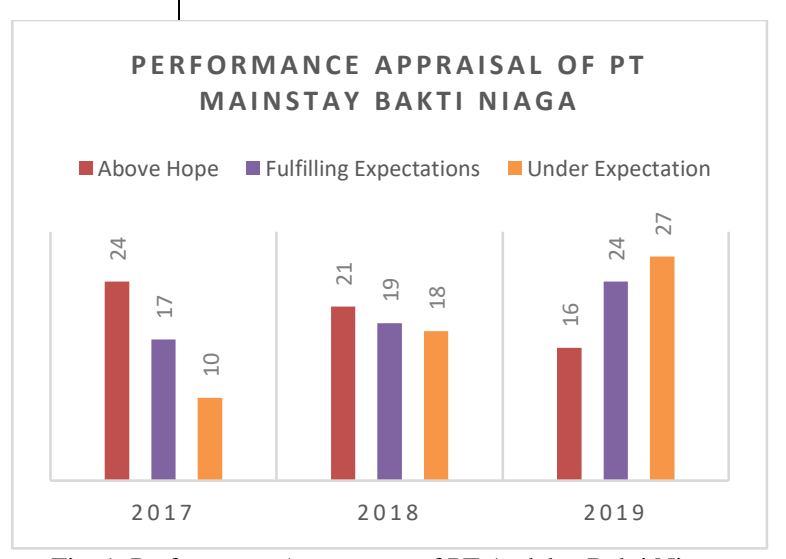

Fig. 1. Performance Assessment of PT Andalan Bakti Niaga.

Based on KPI data for employees of PT Andalan Bakti Niaga from 2017 to 2019. For the performance appraisal indicator "Below Expectations" from year to year has increased. Meanwhile, the indicator "Above Expectations" has decreased from year to year. Thus, if the company must be able to find a solution for the decline in employee performance of PT Andalan Bakti Niaga. 


\section{LITERATURE REVIEW}

\section{A. Theoretical Review}

\section{Green Human Resource Management}

According to Pinzone et al. [1] Green Human Resource Management facilitates employee involvement in environmental management, manifested in a joint commitment to change actions in order to support companies in their efforts to implement environmental management (protection). GHRM can be focused on systemic planning related to human resource management practices in accordance with company objectives in environmental management. With the increasing number of studies on organizational greening, it has become clear that currently companies need the support of human resource practices to implement greening such as recruitment, training, performance evaluation and rewards for employees.

\section{Green Recruitment}

According to Nawangsari and Sutawidjaya [2], Green Recruitment is a way to get candidates who are in accordance with existing positions in the company through an online process and the recruited candidates can maintain environmental values. Green Recruitment is an online recruitment process for employee candidates to produce employee candidates who match the position desired by the company and enter environmental criteria. The recruitment process is expected to produce candidates who are committed to the environment and willing to contribute to the company. According to Bernardin \& Russel [3], the dimensions of Green Recruitment are recruitment candidates, selection providers and selection criteria.

\section{Green Training}

According to Jabbour \& Jabbour [4], Green Training refers to a system of activities that motivates employees to learn environmental protection skills and pay attention to environmental issues, which are key in achieving environmental goals. Training can increase employee awareness, knowledge and skills in environmental activities. Green Training can help employees understand more about the importance of protecting the environment, which makes them more sensitive to the environmental control process. According to Jabbour [5], the dimensions of Green Recruitment are the quality of training, training opportunities, quantity of training, evaluation of training and training effectiveness.

\section{Green Performance Appraisal}

Green Performance Appraisal is a system for evaluating employee performance activities in the environmental management process. According to Delmonico et al. [6] Green Performance management creates green performance indicators to establish a set of green criteria for all members in performance appraisals, covering topics such as environmental incidents, environmental responsibility, reducing carbon emissions, and communicating concerns and policies environment. According to Tang et al. [7], the dimensions of the Green Performance Appraisal are management, performance appraisal and performance evaluation.

\section{Green Compensation and Reward}

According to Latan et al. [8], a strategic approach to the management of Green Compensation and Rewards is a financial and non-financial reward system, which aims to attract, retain, and motivate employees to contribute to environmental goals. Employees may feel more motivated by non-financial rewards through green pay and rewards, such as recognition and praise. Incentives and rewards may be a more powerful measure for aligning employee performance with company goals than other practices in the HRM system. According to Bernardin \& Russel [3], the dimensions of Green Compensation and Reward are rewards and incentives.

\section{Organization Citizenship Behavior for Environment (OCBE)}

According to Sinaga and Nawangsari [9], OCBE is someone's voluntary behavior that aims to improve the environment. These individual behaviors can be said to be like sharing knowledge to prevent pollution in the workplace and suggesting solutions aimed at reducing waste. OCBE is voluntary individual behavior (not an action that is forced) towards things that promote the interests of the company and environmental improvement. According to Boiral et al. [10], the dimensions and indicators of OCBE are Eco-initiatives, Eco-civic engagement, and Eco-helping.

\section{Employee performance}

Employee performance is the work done by employees who have been determined by the organization in accordance with their duties and responsibilities as well as performance evaluation carried out by the organization in order to achieve organizational goals. According to Tarigan and Rozzyana [11], employee performance can be seen from work performance, order, loyalty, responsibility, creativity and employee knowledge. Performance implementation is carried out by human resources who have the ability, competence, motivation and interests. According to Mathis and Jackson [12] in Sinaga and Nawangsari [9], measurement of performance can be carried out through several dimensions including work quality, work quantity, timeliness, attendance and cooperation ability.

\section{B. Hypothesis Development}

1. Relationship between Green Recruitment and Organization Citizenship Behavior for Environment $(O C B E)$

Sinaga and Nawangsari [9] said that Green Training has a positive and significant effect on OCBE.

Hypothesis 1: Green Recruitment has a significant and significant effect on Organization Citizenship Behavior for Environment (OCBE).

\section{Relationship between Green Training and Organization Citizenship Behavior for Environment $(O C B E)$}

Pham et al. [13] revealed that Green Training has a positive influence on OCBE. Green training plays an important role in improving OCBE.

Hypothesis 2: Green Training has a significant and significant effect on Organization Citizenship Behavior for Environment (OCBE).

3. Relationship between Green Performance Appraisal and Organization Citizenship Behavior for Environment (OCBE)

Alnajdawi et al. [14] stated that there is a positive and significant effect of the Green Performance Appraisal on 
Organization Citizenship Behavior for Environment. The Green Performance Appraisal covers matters regarding green environmental awareness to be in line with OCBE.

Hypothesis 3: Green Performance Appraisal significant and influential on Organization Citizenship Behavior for Environment (OCBE).

4. Relationship between Green Compensation and Reward with Organization Citizenship Behavior for Environment (OCBE)

In the research of Silvester et al. [15] revealed that there is a significant relationship with Green Compensation and Reward on OCBE. With the existence of Green Compensation and Reward, employees feel that their ideas and suggestions covering green behavior will be appreciated by the company.

Hypothesis 4: Green Compensation and Reward has a significant and significant effect on Organization Citizenship Behavior for Environment (OCBE).

5. Relationship between Green Human Resource Management and Organization Citizenship Behavior for Environment (OCBE)

According to Mohammad et al. [16], Green Human Resource Management has a positive influence on the Organization Citizenship Behavior for Environment.

Hypothesis 5: Green Human Resource Management simultaneously and significantly influences Organization Citizenship Behavior for Environment (OCBE).

6. Relationship between Green Recruitment and Employee Performance

Oaya et al. [17] in a research journal said that green recruitment has a significant effect on employee performance. A good recruitment strategy allows companies to get quality employees who can improve the performance of these employees.

Hypothesis 6: Green Recruitment has an effect and is significant on Employee Performance.

7. Relationship between Green Training and Employee Performance

Sinaga and Nawangsari [9] reveal that Green Training has a positive and significant impact on employee performance. For this reason, employees must be provided with training and education in order to develop skills and knowledge needed in the organization.

Hypothesis 7: Green Training influential and significant on employee performance.

8. Relationship between Green Performance Appraisal and Employee Performance

Ardiza \& Nawangsari research [18] reveals that Green performance appraisal has a significant positive effect on employee performance. Performance appraisal that is done properly and professionally can increase employee loyalty and motivation so that organizational goals can also be achieved as expected.

Hypothesis 8: Green Performance Appraisal influential and significant on employee performance.

9. Green Compensation and Reward Relationship with Employee Performance

Research by Saeed and Afsar [19] states that there is a positive effect of Green Compensation and Reward on employee performance. With the strongest competency bonus dimension.
Hypothesis 9: Green Compensation and Reward influential and significant on employee performance.

10. Relationship between Green Human Resource Management and Employee Performance

Research by Saeed and Afsar [19] states that all Green Human Resource Management practices have a positive effect and have a significant correlation with Employee Performance.

Hypothesis 10: Green Human Resource Management simultaneous and significant influence on employee performance.

11. Relationship between Organization Citizenship Behavior for Environment (OCBE) and Employee Performance

Ardiza and Nawangsari [18] state that OCBE has a significant positive effect on employee performance. Environmentally friendly behavior has a good impact on improving employee performance.

Hypothesis 11: Organization Citizenship Behavior for Environment (OCBE) has a significant effect on employee performance.

12. Relationship between Green Recruitment and Employee Performance through Organization Citizenship Behavior for Environment (OCBE)

Sinaga and Nawangsari research [9] reveals that Green Recruitment has a positive and significant effect on employee performance through OCBE.

Hypothesis 12: Green Recruitment affect Employee Performance through Organization Citizenship Behavior for Environment (OCBE).

13. The Relationship between Green Training and Employee Performance through the Organization Citizenship Behavior for Environment (OCBE)

Research Alnajdawi et al. [14] revealed that the Organization Citizenship Behavior for Environment (OCBE) fully mediates the relationship between Green Training and Employee Performance.

Hypothesis 13: Green Training affect Employee Performance through Organization Citizenship Behavior for Environment (OCBE).

14. Relationship between Green Performance Appraisal and Employee Performance through Organization Citizenship Behavior for Environment (OCBE)

Ardiza and Nawangsari [18] revealed that Green Performance Appraisal through OCBE has a significant positive effect on Employee Performance.

Hypothesis 14: Green Performance Appraisal affect Employee Performance through Organization Citizenship Behavior for Environment (OCBE).

15. Relationship between Green Compensation and Rewards with Employee Performance through Organization Citizenship Behavior for Environment (OCBE)

Alnajdawi et al. [14] revealed that Green Compensation and Rewards through OCBE has a significant positive effect on employee performance.

Hypothesis 15: Green Compensation and Reward affect Employee Performance through Organization Citizenship Behavior for Environment (OCBE). 


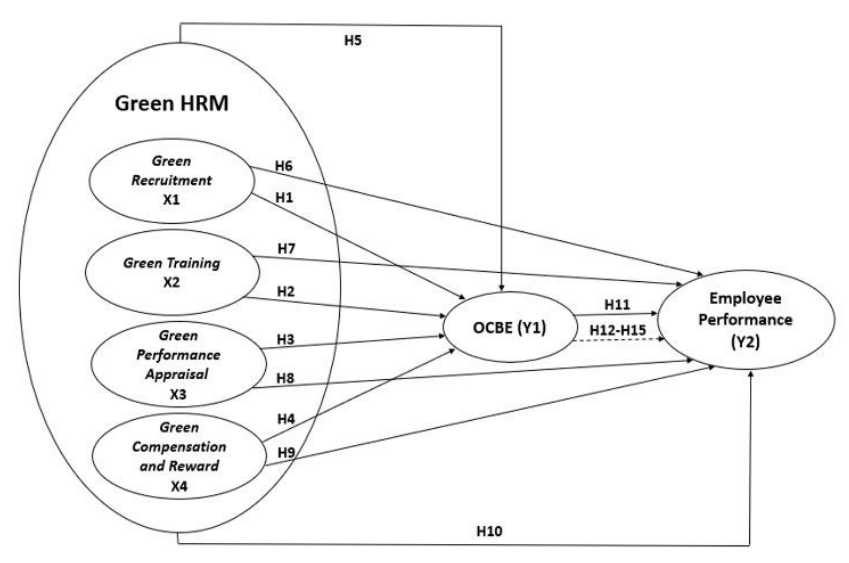

Fig. 2. Research Framework. Source: Self-processed (2020).

\section{METHODS}

\section{A. Research Design}

This type of research is quantitative using primary data in the form of surveys. The independent variable in this study is Green Human Resource Management (Green Recruitment, Green Training, Green Performance Appraisal and Green Compensation and Reward), the mediating variable is OCBE and the dependent variable is Employee Performance.

\section{B. Population and Sample}

The population in this study were 80 employees of PT Andalan Bakti Niaga. The sample of this study used a nonprobability sampling technique, namely saturated sampling. Therefore, the sample in this study were all 80 employees of PT Andalan Bakti Niaga.

\section{Data Collection Methods}

In this research is literature study, interview and questionnaire. The data collected from this study consisted of primary data (questionnaires) and secondary data (books, journals and articles). This research refers to the Likert scale.

\section{Data Analysis Techniques}

The data analysis in this study used a component or variance based structural equation. In processing the data using Partial Least Square (Smart-PLS) version 3.2.7. In PLS Path Modeling, there are 2 models, namely the outer model and the inner model.

\section{DISCUSSION}

\section{A. Testing the Measurement Model (Outer Model)}

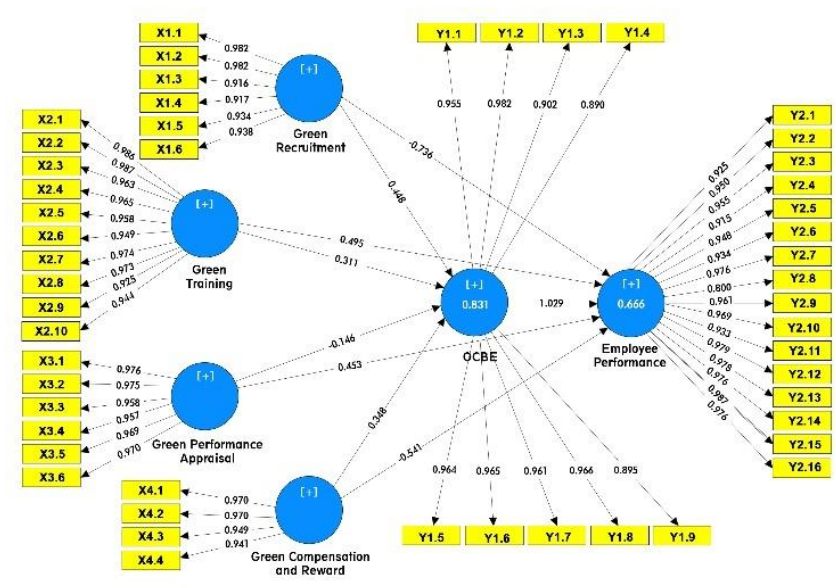

Fig. 3. Testing the Inner Model - Path Coefficient. Source: The results of the analysis using Smart PLS 3.2.7.

\section{B. Convergent Validity}

The Convergent Validity test is the factor loading value on the latent variable with its indicator. The rule of thumb used for convergent validity is a loading factor $>0,7$. Based on the measurement model above, all variable indicators each have a loading factor value $>0,7$. It can be concluded that all variable indicators are valid and are still used in the model or not excluded from the model.

\section{Average Variance Extracted (AVE)}

According to Abdillah and Hartono [20], the evaluation of convergent validity can be seen from the value of Average Variance Extracted (AVE) > 0,50.

TABLE 1: AVERAGE VARIANCE EXTRACTED (AVE) VALUE OF EACH

\begin{tabular}{lc}
\multicolumn{2}{c}{ VARIABLE } \\
\hline \multicolumn{1}{c}{ Variable } & $\begin{array}{c}\text { Average Variance } \\
\text { Extracted (AVE) Value }\end{array}$ \\
\hline Green Recruitment & 0.777 \\
Green Training & 0.811 \\
Green Performance Appraisal & 0.843 \\
Green Compensation and Reward & 0.891 \\
OCBE & 0.829 \\
Employee performance & 0.727 \\
\hline
\end{tabular}

Source: The results of the analysis using Smart PLS 3.2.7.

In the table above it is known that all variables have an AVE value $>0,5$. So that each variable in this study has met the good convergent validity requirements.

\section{Cronbach's Alpha and Composite Reliability}

According to Ghozali and Latan [21], a construct is declared reliable if the Composite Reliability value is $>0,7$ and Cronbach Alpha > 0,60.

TABLE 2: CRONBACH ALPHA AND COMPOSITE RELIABILITY (CR)

\begin{tabular}{|c|c|c|c|c|c|}
\hline Variable & $\begin{array}{c}\text { Cronbach's } \\
\text { Alpha }\end{array}$ & Standard & $\begin{array}{l}\text { Composite } \\
\text { Reliability }\end{array}$ & Standard & Result \\
\hline Green Recruitment & 0.943 & $>0.70$ & 0.954 & $>0.60$ & Reliable \\
\hline Green Training & 0.974 & $>0.70$ & 0.977 & $>0.60$ & Reliable \\
\hline $\begin{array}{c}\text { Green Performance } \\
\text { Appraisal }\end{array}$ & 0.963 & $>0.70$ & 0.970 & $>0.60$ & Reliable \\
\hline $\begin{array}{c}\text { Green Compensation } \\
\text { and Reward }\end{array}$ & 0.959 & $>0.70$ & 0.970 & $>0.60$ & Reliable \\
\hline OCBE & 0.974 & $>0.70$ & 0.978 & $>0.60$ & Reliable \\
\hline $\begin{array}{l}\text { Employee } \\
\text { performance }\end{array}$ & 0.975 & $>0.70$ & 0.977 & $>0.60$ & Reliable \\
\hline
\end{tabular}




\section{E. Evaluation of the Structural Model (Inner Model)}

The inner model is a structural model that describes the causality relationship between latent variables.

TABLE 3: SimultanEOUS EFFECT TESTING RESUlts (R-SQUARED)

\begin{tabular}{ccc}
\hline & $\begin{array}{c}\text { R- } \\
\text { squared }\end{array}$ & $\begin{array}{c}\text { R2 } \\
\text { Adjusted }\end{array}$ \\
\hline OCBE & 0.831 & 0.822 \\
Employee performance & 0.666 & 0.646 \\
\hline
\end{tabular}

Source: The results of the analysis using Smart PLS 3.2.7.

The relationship between constructs based on the Adjusted R2 Adjusted value can be explained that the OCBE variable is 0,822 . This shows that $82,2 \%$ of the OCBE variable can be influenced by the Green Recruitment, Green Training, Green Performance Appraisal and Green Compensation and Reward variables, while the remaining $17,8 \%$ is influenced by other variables not examined in this study.

For the Adjusted R2 Adjusted value, the Employee Performance variable is 0,646 . This shows that $64,6 \%$ of Employee Performance variables can be influenced by Green Recruitment, Green Training, Green Performance Appraisal, Green Compensation and Rewards and OCBE, while the remaining $35,4 \%$ is influenced by other variables not examined in this study.

\section{F. Research Hypothesis Testing}

TABLE 4: THE INFLUENCE OF PARTIALLY INDEPENDENT VARIABLES ON DEPENDENT VARIABLES

\begin{tabular}{|c|c|c|c|c|c|c|}
\hline & Variable & $\begin{array}{c}\text { Original } \\
\text { Sample }(\mathrm{O}) \\
\end{array}$ & $\begin{array}{l}\text { T Statistics } \\
\text { (O /STDEV) }\end{array}$ & $\begin{array}{c}\mathrm{T} \\
\text { Table }\end{array}$ & $\begin{array}{c}\mathrm{P} \\
\text { Values }\end{array}$ & Result \\
\hline $\mathrm{H} 1$ & Green Recruitment $=>\mathrm{OCBE}$ & 0.448 & 3,384 & 1.96 & 0.001 & Accepted \\
\hline $\mathrm{H} 2$ & Green Training => OCBE & 0.311 & 2,169 & 1.96 & 0.031 & Accepted \\
\hline $\mathrm{H} 3$ & Green Performance Appraisal => OCBE & -0.146 & 0.803 & 1.96 & 0.423 & Rejected \\
\hline $\mathrm{H} 4$ & Green Compensation and Reward $=>\mathrm{OCBE}$ & 0.348 & 2,746 & 1.96 & 0.006 & Accepted \\
\hline H6 & Green Recruitment $\Rightarrow>$ Employee Performance & $-0,736$ & 5,295 & 1.96 & 0,000 & Accepted \\
\hline $\mathrm{H} 7$ & Green Training => Employee Performance & 0.495 & 3,002 & 1.96 & 0.003 & Accepted \\
\hline H8 & Green Performance Appraisal=> Employee Performance & 0.453 & 2,491 & 1.96 & 0.013 & Accepted \\
\hline H9 & Green Compensation and Reward $=>$ Employee Performance & -0.541 & 3,269 & 1.96 & 0.001 & Accepted \\
\hline H11 & $\mathrm{OCBE}=>$ Employee Performance & 1,029 & 6,236 & 1.96 & 0,000 & Accepted \\
\hline
\end{tabular}

Source: The results of the analysis using Smart PLS 3.2.7.

TABLE 5: THE EFFECT OF INDEPENDENT VARIABLES SIMULTANEOUSLY ON DEPENDENT VARIABLES

\begin{tabular}{clccccc}
\multicolumn{2}{c}{ Variable } & \multirow{2}{*}{ R2 } & $\begin{array}{c}\mathrm{F} \\
\text { TABtistics }\end{array}$ & $\begin{array}{c}\mathrm{F} \\
\text { Table }\end{array}$ & \multirow{2}{*}{ Alpha } & Result \\
\hline H5 & GHRM (GR, GT, GC and GP) => OCBE & 0.831 & 72.77 & 2.34 & 0.05 & Accepted \\
H10 & GHRM (GR, GT, GC GP) and OCBE => KK & 0.666 & 29.51 & 2.34 & 0.05 & Accepted \\
\hline
\end{tabular}

Source: The results of the analysis using Smart PLS 3.2.7.

TABLE 6: INDIRECT EFFECT VARIABLE INDEPENDENT OF DEPENDENT VARIABLES

\begin{tabular}{|c|c|c|c|c|c|c|c|c|}
\hline & Variable & $\begin{array}{c}\text { Original } \\
\text { Sample } \\
(\mathrm{O})\end{array}$ & $\begin{array}{c}\text { Sample } \\
\text { Mean } \\
(\mathrm{M})\end{array}$ & $\begin{array}{c}\text { Standard } \\
\text { Deviation } \\
\text { (STDEV) }\end{array}$ & $\begin{array}{l}\text { T Statistics } \\
(\mathrm{O} / \mathrm{STDEV})\end{array}$ & $\begin{array}{c}\mathrm{T} \\
\text { Table }\end{array}$ & $\begin{array}{c}\mathrm{P} \\
\text { Values }\end{array}$ & Result \\
\hline H12 & $\begin{array}{l}\text { Green Recruitment to Employee } \\
\text { Performance through OCBE }\end{array}$ & 0,461 & 0,452 & 0,166 & 2.777 & 1,96 & 0,006 & Accepted \\
\hline H13 & $\begin{array}{l}\text { Green Training to Employee } \\
\text { Performance through OCBE }\end{array}$ & 0,320 & 0,329 & 0,161 & 1,987 & 1,96 & 0,047 & Accepted \\
\hline H14 & $\begin{array}{c}\text { Green Performance Appraisal to } \\
\text { Employee Performance through OCBE }\end{array}$ & $-0,150$ & $-0,162$ & 0,193 & 0,776 & 1,96 & 0,438 & Rejected \\
\hline H15 & $\begin{array}{l}\text { Green Compensation and Reward to } \\
\text { Employee Performance through OCBE }\end{array}$ & 0,359 & 0,358 & 0,140 & 2,562 & 1,96 & 0,011 & Accepted \\
\hline
\end{tabular}

Source: The results of the analysis using Smart PLS 3.2.7.

Hypothesis testing in this study is as follows:

1) The Effect of Green Recruitment on OCBE

Based on observations at PT Andalan Bakti Niaga regarding Green Recruitment, the company has implemented an online-based recruitment system by making prospective new employees have knowledge and concern for the environment. So that with these conditions, will help improve the quality of environmental awareness for employees. Therefore, the H1 hypothesis in this study which states that "Green Recruitment has a significant and significant effect on OCBE" is accepted.

2) The Effect of Green Training on OCBE

Green Training plays an important role in increasing OCBE, because it can encourage employees to engage in environmentally friendly behavior. In the Green Training process carried out by PT Andalan Bakti Niaga, it has been running optimally and structured. Green Training can build green competencies that encourage employees to go the extra mile in environmental activities and become involved voluntarily. Therefore, the $\mathrm{H} 2$ hypothesis in this study which states that "Green Training has a significant and significant effect on OCBE", is accepted.

3) The Effect of Green Performance Appraisal on OCBE

Based on observations at PT Andalan Bakti Niaga, the implementation of the Green Performance Appraisal system is still not optimal. The company has not provided comprehensive knowledge regarding OCBE which is included in the Green Performance Appraisal. Lacking this information, employees feel that environmental behavior is not included in performance appraisals. Therefore, the hypothesis $\mathrm{H} 3$ in this study which states that "Green Performance Appraisal has a significant and significant effect on OCBE", is rejected.

4) The Effect of Green Compensation and Reward on OCBE

Green Compensation and Rewards makes employees have an environmentally friendly attitude. This result is 
consistent with the conditions at PT Andalan Bakti Niaga, Green Compensation and Rewards have an impact on increasing employee motivation to continue to behave in an environmentally friendly manner. In addition, employees also feel that their ideas and suggestions regarding green behavior will be appreciated by the company. Therefore, the hypothesis $\mathrm{H} 4$ in this study which states that Green Compensation and Reward has a significant and significant effect on OCBE", is accepted.

5) The Simultaneous Effect of Green Human Resource Management on OCBE

Green Human Resource Management (Green Recruitment, Green Training, Green Compensation and Rewards and Green Performance Appraisal) are formed from policies that support environmentally friendly behavior in the company. This is in accordance with the conditions at PT Andalan Bakti Niaga, employees have understood that the company has a commitment to the environment that they can instill such as being committed to its environmental mission and engaging in environmentally friendly behavior in every work activity. Therefore, the hypothesis H5 in this study which states that "Green Human Resource Management simultaneously and significantly affects OCBE", is accepted.

6) The Effect of Green Recruitment on Employee Performance

A good recruitment strategy allows companies to get quality employees. The online-based recruitment process at PT Andalan Bakti Niaga has been carried out well. Because most of the employees are sales and with high school / vocational and fresh graduate education backgrounds. This is one of the factors causing the decline in employee performance, because it has not met company targets. Therefore, the hypothesis H6 in this study which states that "Green Recruitment has a significant and significant effect on Employee Performance", is accepted.

7) The Effect of Green Training on Employee Performance

Green Training has an important role in terms of improving employee performance. Employees feel that the training provided by the company can motivate employees to improve their performance. Especially at this time PT Andalan Bakti Niaga started trying to use e-learning or online-based training methods. Therefore, the hypothesis $\mathrm{H} 7$ in this study which states that "Green Training has a significant and significant effect on Employee Performance", is accepted.

8) The Effect of Green Performance Appraisal on Employee Performance

Based on observations at PT Andalan Bakti Niaga, that the Green Performance Appraisal can improve employee performance. With the Green Performance Appraisal, employees feel there are certain benchmarks for their performance so far. So that it makes employees always excited to work to get good Green Performance Appraisal results. Therefore, the hypothesis $\mathrm{H} 8$ in this study which states that "Green Performance Appraisal has a significant and significant effect on Employee Performance", is accepted.

9) The Effect of Green Compensation and Reward on Employee Performance
Based on observations at PT Andalan Bakti Niaga that Green Compensation and Rewards have not been maximally implemented. For that the company must evaluate return the standards used as a reference in determining the compensation and rewards to employees. So that employees can feel that they are treated fairly and in accordance with the work that has been achieved. Therefore, the hypothesis H9 in this study which states that "Green Compensation and Reward has a significant and significant effect on Employee Performance", is accepted.

10) The Simultaneous Effect of Green Human Resource Management on Employee Performance

The development of Green Human Resource Management at PT Andalan Bakti Niaga has improved employee performance. Moreover, Green Human Resource Management enables employees to identify the suitability and harmony between their values and the company's values. Then improving the identification of the company will improve employee performance. Therefore, the hypothesis $\mathrm{H} 10$ in this study which states that "Green Human Resource Management simultaneously and significantly affects Employee Performance", is accepted.

11) Effect of OCBE on Employee Performance

Knowledge of OCBE makes employees understand more about environmentally friendly behavior and motivated to have good performance. The implementation of OCBE at PT Andalan Bakti Niaga has a good impact on employee performance. Good habits of employees with environmental concerns will improve the quality of employee performance. Therefore, the hypothesis H11 in this study which states that "OCBE has a significant and significant effect on Employee Performance", is accepted.

12) The Effect of Green Recruitment on Employee Performance Through OCBE

Based on observations at PT Andalan Bakti Niaga, Green Recruitment has been carried out using an online process by adding criteria for environmentally friendly behavior. The goal is that employees have voluntary behavior towards the environment and are motivated to complete their work well. Therefore, the hypothesis $\mathrm{H} 12$ in this study which states that "Green Recruitment has a significant and significant effect on Employee Performance through OCBE", is accepted.

13) The Effect of Green Training on Employee Performance Through OCBE

Based on observations at PT Andalan Bakti Niaga, the Green Training carried out by the company has used an online learning system or an e-learning process. The company has also added material on environmentally friendly behavior to the training and development process for employees. This is what makes employees feel concerned and responsible for the environment in the workplace and can affect employee performance improvement. Therefore, the hypothesis H13 in this study which states that "Green Training has a significant and significant effect on Employee Performance through OCBE", is accepted.

14) The Effect of Green Performance Appraisal on Employee Performance through OCBE

Based on observations at PT Andalan Bakti Niaga, the implementation of the Green Performance Appraisal is still not optimal. This is because there are still many employees 
who do not know and understand about green environmental behavior, which is a benchmark for employee performance appraisal in the company. To achieve good Green Performance Appraisal results and good performance appraisals. Human resource management needs to do outreach return to all employees regarding the overall performance appraisal criteria. In order to make employees more enthusiastic about improving work quality and having a sense of responsibility in protecting the environment. Therefore, the hypothesis H14 in this study which states that "Green Performance Appraisal has a significant and significant effect on Employee Performance through OCBE", is rejected.

15) The Effect of Green Compensation and Rewards on Employee Performance through OCBE

Based on observations at PT Andalan Bakti Niaga that the company has implemented Green Compensation and Rewards well. The company has included green environmental behavior which is included in the employee performance appraisal. If the results of the appraisal are good, then the employees will get certain compensation or rewards for their performance and hard work so far. This makes employees have the awareness to improve their performance and be active in protecting the environment. Therefore, the hypothesis H15 in this study which states that "Green Compensation and Rewards have a significant and significant effect on Employee Performance through OCBE", is accepted.

\section{CONCLUSIONS AND SUGGESTIONS}

\section{A. Conclusion}

Based on the analysis of the research results, the following conclusions were obtained:

1) Green Recruitment positive and significant effect on Organization Citizenship Behavior for Environment (OCBE).

2) Green Training positive and significant effect on Organization Citizenship Behavior for Environment (OCBE).

3) Green Performance Appraisal does not have a significant effect on Organization Citizenship Behavior for Environment (OCBE).

4) Green Compensation and Reward positive and significant effect on Organization Citizenship Behavior for Environment (OCBE).

5) Green Human Resource Management simultaneously has a positive and significant effect on Organization Citizenship Behavior for Environment (OCBE).

6) Green Recruitment has a negative and significant effect on employee performance.

7) Green Training positive and significant effect on employee performance.

8) Green Performance Appraisal positive and significant effect on employee performance.

9) Green Compensation and Reward has a negative and significant effect on employee performance.

10) Green Human Resource Management simultaneously have a positive and significant effect on employee performance.
11) Organization Citizenship Behavior for Environment (OCBE) has a positive and significant effect on employee performance.

12) Green Recruitment has a significant effect on Employee Performance through Organization Citizenship Behavior for Environment (OCBE).

13) Green Training significant effect on Employee Performance through Organization Citizenship Behavior for Environment (OCBE).

14) Green Performance Appraisal does not have a significant effect on Employee Performance through Organization Citizenship Behavior for Environment (OCBE).

15) Green Compensation and Reward has a significant effect on Employee Performance through Organization Citizenship Behavior for Environment (OCBE).

\section{B. Suggestion}

Based on the results of this study, the suggestions that can be conveyed include the following:

\section{For Companies}

1) HR management needs to include environmental criteria in the recruitment process. So that employees can better understand how to protect the environment and be able to complete tasks properly.

2) HR management needs to evaluate employee performance based on employees who have attended environmental training and are active in environmental activities. So that employees will have a commitment to protecting the environment and are responsible for completing their work.

3) Companies need to add an incentive package in the compensation bonus component for employees who behave in protecting the environment. So that employees can feel the consequences of their actions and are committed to doing the assigned tasks.

4) Companies need to improve the performance appraisal system and inform all employees regarding environmental safeguards included in the performance appraisal. So that employees can be motivated to protect the environment and have good relations with company management.

5) The company is expected to be able to create a CSR (Corporate Social Responsibility) program, to increase employee awareness of the environment. So that employees can participate actively in protecting the environment and increasing their ability to complete their work.

\section{For Further Researchers}

1) The number of respondents used in this study is very limited. For this reason, the accuracy of further research can be improved by using more respondent data, for example 100 to 300 respondents.

2) Based on the results of this study there are other variables of $35.4 \%$ which were not examined in this study. So that the influence of these variables is not known how the relationship and its effect on Employee Performance through OCBE. Further research is suggested to dig deeper related to other variables that can affect employee performance through OCBE. 


\section{REFERENCES}

[1] M. Pinzone, M. Guerci, E. Lettieri, and T. Redman. (2016) Progressing in the change journey towards sustainability in healthcare: The role of "Green" HRM. Journal of Cleaner Production. [Online]. vol. 122, pp. 201-211. Available: https://www.sciencedirect.com/science/article/pii/S09596526160017 61.

[2] L. C. Nawangsari, and A. H. Sutawidjaya. (2019). How the Green Human Resources Management (GHRM) Process Can Be Adopted for the Organization Business?. Atlantis Press. [Online]. ICBEF 2018, 463-465. Available: https://www.atlantis-press.com/proceedi ngs/iceb ef-18/125908114.

[3] C. I. Bernardin, dan Russel, Pinter Manajer, Aneka Pandangan Kontemporer. Alih Bahasa Agus Maulana. Binarupa Aksara, Jakarta, 2016.

[4] C. J. C. Jabbour, and A. B. L. de Sousa Jabbour. (2016). Green human resource management and green supply chain management: Linking two emerging agendas. Journal of Cleaner Production. [Online]. 112 (3), 1824-1833. Available: https://www.sciencedirect. com/science/article/pii/S0959652615000566.

[5] C. J. C. Jabbour, D. Jugend, A. B. L. de Sousa Jabbour, A Gunasekaran, and H. Latan. (2015). Green product development and performance of Brazilian firms: measuring the role of human and technical aspects. Journal of Cleaner Production. [Online]. 87, 442451. Available: https://www.sciencedirect.com/science/article/pii/S0 959652614009664.

[6] D. Delmonico, C. J. C. Jabbour, S. C. F. Pereira, A. B. L. de Sousa Jabbour, D. W. S. Renwick, and A. M. T. Thomé. (2018). Unveiling barriers to sustainable public procurement in emerging economies: evidence from a leading sustainable supply chain initiative in Latin America. Resources, Conservation and Recycling. [Online]. 134, 7079, ISSN 0921-3449. Available: https://www.sciencedirect.com/ science/article/pii/S0921344918300922.

[7] G. Tang, Y. Chen, Y. Jiang, P. Paillé, and J. Jia. (2018). Green human resource management practices: Scale development and validity. Asia-Pacific Journal of Human Resources. [Online]. vol. 56 (1), pp. 31-55. Available: https://onlinelibrary.wiley.com/doi/abs/ 10.1111/17 44-7941.12147.

[8] H. Latan, C. J. C. Jabbour, A. B. L. de Sousa Jabbour, D. W. S. Renwick, S. F. Wamba, and M. Shahbaz. (2018). 'Too-much-of-agood-thing'? The role of advanced eco-learning and contingency factors on the relationship between corporate environmental and financial performance. Journal of environmental management. [Online]. 220, 163-172. Available: https://www.sciencedirect. com/science/article/pii/S0301479718305310.

[9] S. A. Sinaga, \& L. C. Nawangsari. (2019). The Effect of Green Recruitment, Green Training on Employee Performance in PT TRU Using Organization Citizenship for Environment as Mediation Variable. Dinasti International Journal of Management Science. [Online]. vol. 1 (2), pp. 204-216. Available: https://dinastipub.org/ DIJMS/article/view/57.

[10] O. Boiral, D. Talbot, and P. Paille, "Leading by Example: A Model of Organizational Citizenship Behavior for the Environment," Business Strategy and The Environment. 24: 532- 550, 2015.

[11] Y. Tarigan, and R. Rozzyana. (2018). Pengaruh Kepemimpinan, Motivasi Dan Lingkungan Kerja Terhadap Kinerja Karyawan. Journal of Applied Managerial Accounting. [Online]. vol. 2 (1), pp. 26-40. Available: https://jurnal.polibatam.ac.id/index.php/JAMA/arti cle/view/659.

[12] R. L. Mathis and J. H. Jackson. Manajemen Sumber Daya Manusia. Edisi Pertama. Salemba Empat, Jakarta. 2012.

[13] N. T. Pham, Q. P. T. Phan, Z. Tučková, N. Vo, and L. H. L. Nguyen. (2018). Enhancing the organizational citizenship behavior for the environment: The roles of green training and organizational culture. Management and Marketing. [Online]. vol. 13 (4), pp. 1174-1189. Available: https://content.sciendo.com/view/journals/mmcks/13/4/ar ticle-p1174.xml?product=sciendo.

[14] S. Alnajdawi, O. L. Emeagwali, and H. Elrehail. (2017). The interplay among green human resource practices, organization citizenship behavior for environment and sustainable corporate performance: Evidence from Jordan. Journal of Environmental Accounting and Management. [Online]. vol. 5 (3), pp. 171-184. Available: https://publons.com /publon/2723068/.

[15] Y. Silvester, A. Sarip, and M. A. Hassan, The relationship between green HRM practices and organizational citizenship behavior toward environment (OCBE), Journal of Management and Operation Research, vol. 1 (18), pp. 1-7, February 2019.

[16] N. Mohammad, Z. Bibi, J. Karim, and D. Durrani, "Green Human Resource Management Practices and Organizational Citizenship
Behaviour For Environment: The Interactive Effects of Green Passion", International Transaction Journal of Engineering, Management, \& Applied Sciences \& Technologies, vol. 11, pp. 1-10, January 2020.

[17] Oaya., Z. C. Tizhe, O. J. Ogbu, and O. G. Remilekun, "Impact of Recruitment and Selection Strategy on Employees' Performance: A Study of Three Selected Manufacturing Companies in Nigeria", International Journal of Innovation and Economic Development, vol. 3, Issue 3, pp. 32-43, August 2017.

[18] F. Ardiza, and L. C. Nawangsari. (2019). Effect of Green Performance Appraisal and Green Compensation and Rewards Mediated by OCBE to the Performance of Employees PT Telecommunications on Indonesia International (Telin)," International Journal of Innovative Science and Research Technology. [Online]. vol. 4 (12), pp. 702-709. Available: https://ijisrt.com/effect-of-green-performance-appraisal-and-grencom pensation-and-rewards-mediated-by-ocbe-to-the-performance-of-em ployees-pt-telecommunications-indonesia-international-telin.

[19] B. B. Saeed, B. Afsar, S. Hafeez, I. Khan, M. Tahir, Afridi, and M. Asim, Promoting employee's proenvironmental behavior through green human resource management practices, Corp Soc Resp Env $M a$, vol. 26, pp. 424-438, October 2018.

[20] W. Abdillah and Hartono, Partial Least Square (PLS), Penerbit: Andi, Yogyakarta, 2015.

[21] Ghozali, Imam, and H. Latan, Konsep, Teknik, Aplikasi Menggunakan Smart PLS 3.0 Untuk Penelitian Empiris, BP Undip, Semarang, 2015. 